\title{
A PAISAGEM ORIGINAL DAS CAPITAIS PLANEJADAS DO CERRADO
}

\author{
THE ORIGINAL LANDSCAPE OF THE NEW TOWNS IN THE BRAZILIAN CERRADO
}

\author{
Júlio Barêa Pastore \\ Agrônomo pela UFG, mestre em Paisagismo pela Università degli Studi di Firenze - Dipartimento di \\ Urbanistica e Pianificazione del Territorio e doutorando pela FAUUSP \\ e-mail: jbpastore@gmail.com
}

\section{RESUMO}

As mais novas capitais brasileiras, Goiânia (1933), Brasília (1960) e Palmas (1989), foram erguidas "di sana pianta" como parte de um impulso de ocupação do centro do país. Neste artigo ressalta-se que elas corporificam projetos de vida urbana e moderna no contexto específico que é o do Cerrado do interior do Brasil.

Buscamos, nos planos originais dessas capitais, como cada um deles respondeu à percepção da natureza da região, e o modo como o Cerrado - vivenciado enquanto paisagem - foi, porventura, neles representado.

Palavras-chave: Paisagem, Cerrado, Goiânia, Brasília, Palmas

\section{ABSTRACT}

The most recent Brazilian capitals, Goiânia (1933), Brasilia (1960) and Palmas, were built "di sana pianta" as part of an intent to occupy the central area of the country. In this article it is emphasized that they embody urban modern life projects in the specific context of the Brazilian's Cerrado.

We seek, in the original plans of these capitals, how each one of them responded to the perceptions of the region's nature, and how the Cerrado - experienced as landscape - was, perhaps, in them represented.

Keywords: Landscape, Cerrado, Goiânia, Brasília, Palmas

\section{INTRODUÇÃO}

Planejar uma capital, uma nova capital, em pleno Cerrado do Planalto Central do Brasil. Desta maneira, pelo traço do urbanista, surgiram Goiânia, Brasília e Palmas. Neste artigo buscaremos compreender se, e de que maneira, o Cerrado pôde ser paisagem para essas cidades nascentes, através do modo como seus planos originais se voltaram ao território que os acolheria. Nisto, acreditamos, poderá estar contida a proposta inaugural de paisagem dessas capitais.

Dentro da profusão de significados do termo "paisagem", privilegiamos aqui seus significados mais íntimos, ressaltados pela fenomenologia: modo primordial de experimentação da Terra pelo homem. Impressão que emerge ao olhar quando este reconhece no campo que se abre à vista uma unidade de sentido nova, independente da soma dos seus elementos particulares tomados isoladamente. Experiência de cunho estético, posto que radicada numa impressão dos sentidos. Experiência que depuramos - especialmente através do trabalho das almas mais sensíveis - e que por fim se mobiliza culturalmente. 
Por reconhecer a apreensão e representação de novos valores de paisagem, a partir da realidade que encontramos, abre-se justamente a esperança de encontrar, no trabalho dos arquitetos que sonharam uma capital moderna imersa na natureza do Cerrado, um gesto fundador.

Na qualidade de cidades planejadas, a primeira realidade de Goiânia, Brasília e Palmas foi, com efeito, o sítio a que pertenceriam? Veremos adiante que, em diversas de suas passagens, os memoriais descritivos dessas capitais indicam que aspectos físicos do sítio escolhido para sua construção foram tomados em consideração e fizeram parte de uma análise objetiva dos potenciais a serem explorados em projeto pelos arquitetos. Poderíamos dizer que tais aspectos chegaram mesmo a influenciar a morfologia geral do desenho urbano: a cidade que se alonga entre elevações e o lago, como Palmas; que se espraia numa longa campina, como Goiânia; ou encaixa-se entre os braços do Lago Paranoá, como Brasília.

Nosso objetivo, porém, não é atestar o nível de adequação ou proveito direto que cada projeto aufere de determinadas características presentes em seu respectivo sítio. O que nos interessa não é a exploração sumária de "recursos naturais" porventura enumerados. Antes, isto será, para nós, material de estudo para o que pretendemos encontrar: como esses projetos se dirigem à paisagem, e como a paisagem, eventualmente, está representada neles.

A questão que colocamos parece pertinente aos três casos selecionados. Para o tipo de análise que pretendemos desenvolver neste artigo, decidimos tratar individualmente - nos itens 3, 4 e 5 - de cada uma das capitais citadas. Não ignoramos que nosso assunto exigiria tratamento mais extenso e vários dos temas que perpassam estas linhas merecem uma análise mais completa. Esperamos poder fazê-lo posteriormente. Não obstante, optamos por tentar desenvolver os três casos neste artigo porque as conclusões a que chegamos, expostas no item 6, pareceram delimitar um caminho mais claro de análise justamente pela exposição desta variedade de casos. De qualquer forma, algumas chaves de reflexão se mostraram importantes nos três casos e acabaram por contribuir na abordagem do problema proposto. São elas:

- O modo como o plano urbanístico responde à localização do sítio escolhido;

- O modo como o plano urbanístico se dispõe sobre o sítio e se relaciona com o entorno imediato;

- Se, e como, o plano urbanístico possui representações paisagísticas do Cerrado.

Por fim, cumpre esclarecer que não faremos, neste artigo, referências às questões ligadas à implantação e ao desenvolvimento das capitais erguidas. Atemo-nos aos planos originais de Goiânia, Brasília e Palmas e, portanto, os principais documentos utilizados foram seus mapas e memoriais. Privilegiamos também outros documentos que fizessem falar os próprios autores: seus textos e entrevistas. 


\section{DOCUMENTOS UTILIZADOS}

No caso de Goiânia (1933), o projeto original consiste do "Relatório do Plano Diretor da Cidade", de Attilio Corrêa Lima, entregue ao interventor federal no Estado de Goiás, Pedro Ludovico, como parte do Plano Diretor da Cidade, em 1935. Este texto foi depois revisto e publicado com algumas modificações, nos três primeiros números da revista Arquitetura e Urbanismo de 1937, como "resumo de um estudo a ser editado futuramente", intitulado "Goiânia: a nova capital de Goiás".

Sobre Brasília utilizamos o projeto entregue em 1957 por Lúcio Costa, para o Concurso Nacional do Plano Piloto da Nova Capital do Brasil, que inclui a planta da cidade, denominada Plano Piloto de Brasília (PPB) e o texto "Memória Descritiva do Plano Piloto", ilustrado com croquis esquemáticos do próprio arquiteto. Também foram particularmente úteis diversos textos e entrevistas de Lúcio Costa, parte deles reunidos no livro Lúcio Costa: Registro de uma vivência, de 1995.

De Palmas (1989) tomamos por referência o texto "Memorial do projeto da capital do estado do Tocantins: Palmas/Plano Básico", de Luiz Fernando Cruvinel Teixeira e Walfredo Antunes de Oliveira Filho, além dos mapas e croquis que fizeram parte da entrega oficial do Plano ao governo do estado durante o lançamento da pedra fundamental de Palmas, em 20 de maio de 1988. Sobre Palmas também citaremos, em especial, a entrevista que me foi concedida pelo arquiteto Luiz Fernando Cruvinel Teixeira, no dia 24 de maio de 2011.

\section{ANÁlISE DOS PLANOS}

\subsection{Goiânia}

Attilio teve a oportunidade de visitar a região escolhida para receber a futura capital em 1932, um ano antes da assinatura do contrato para a elaboração do projeto de Goiânia, de 1933'. O arquiteto - recém-chegado de uma pós-graduação no Instituto de Urbanismo da Universidade de Paris - uma vez contratado, mudou-se para o que era então apenas um canteiro de obras, permanecendo ali pelos três primeiros anos de construção da cidade (1933, 34 e 35). O Plano Diretor da Cidade, redigido por ele, foi entregue ao governador em 1935 - três anos depois de começadas as obras de implantação da cidade - quando então o urbanista se afastou das mesmas e retornou definitivamente ao Rio de Janeiro.

Na publicação do plano de Goiânia, em 1937, o arquiteto expôs as razões da mudança da capital e apreciações sobre o Estado de Goiás. A impressão positiva das terras goianas sobressai no memorial escrito:

"A tarefa de escolha do local sob o ponto de vista físico, foi relativamente fácil, porque não há carência dentro do Estado de sítios salubres, aprazíveis, férteis e ricos em matéria prima." 2 
Testemunha do interesse do arquiteto pela paisagem goiana é uma passagem do memorial em que se discorre sobre a antiga capital, Vila Bôa. Em meio à discriminação dos variados problemas que justificavam a decisão de construir-se novo centro administrativo, Attilio cede a um impulso discordante ao demorar-se num quadro onde registra o gosto pela paisagem vilaboense:

"Milita a natureza em seu favor apenas, pelo aspecto deliciosamente pitoresco. Sua topografia torturada pelo rio encachoeirado, pelos altos morros, pelos vales profundos e sombrios, pelas rochas que emergem em via pública, dão-lhe um aspecto pitoresco, dificilmente igualado (..) suas casas ingenuamente alinhadas com irregularidade e sem interrupção, muito brancas, sobressaindo no fundo imensamente verde, de uma exuberante flora tropical, apaixona mas não a ponto de obstruir a razão." 3

olhar registrado acima contrasta com as palavras duras com que Vila-Bôa costumava ser caracterizada (algumas das quais citadas no mesmo documento pelo próprio arquiteto).

Attilio, acreditamos, lançava àquelas terras um olhar que não era desprovido de intimidade e interesse pela paisagem. $O$ arquiteto trabalhou profissionalmente também como paisagista e lecionou "Urbanismo - Arquitetura paisagística" na Escola Nacional de Belas Artes da Universidade do Rio de Janeiro, entre 1936 e 37. Na sua biblioteca, preservada, se encontram 31 livros sobre paisagismo, a maioria dos quais sobre a flora brasileira, 14 livros sobre arquitetura e 23 sobre urbanismo (ACKEL, 2007).

Goiânia foi pensada com sua parte central estendida sobre uma longa e suave campina, de solo argiloso e profundo. Tinha por limites os córregos Botafogo e Capim Puba. As características do local, de sua geomorfologia, dos cursos dos rios e das águas pluviais, das qualidades do solo e da cobertura vegetal, foram criteriosamente observadas pelo arquiteto, que se decidiu por redefinir o sítio escolhido originalmente para a urbanização:

"Tendo sido escolhido pelo engenheiro João Argenta, encarregado do levantamento topográfico, o local denominado de Paineira, para o assentamento do núcleo inicial, discordamos dessa opinião [...]. Um núcleo urbano construído na Paineira assentaria sobre um terreno de três a quatro por cento de declividade. Ao passo que mais baixo, no local por nós escolhido, essa declividade é em média dois por cento; portanto, muito mais propício para conter a parte central da cidade." 4

Attilio se valeu da topografia para ampliar o caráter monumental que desejava imprimir à cidade e a edifícios específicos:

"Da topografia tiramos partido também para obter efeitos perspectivos com o motivo principal da cidade, que é o centro administrativo. Domina este a região e é visto de todos os pontos da cidade e principalmente por quem nela chega." 
De fato, no desenho de Attilio, a Praça Couto Magalhães (hoje Praça Cívica) domina a malha urbana estruturada por três grandes avenidas que dela partem, formando um vértice de $60^{\circ} \mathrm{com}$ a avenida principal - Avenida Pedro Ludovico, hoje Avenida Goiás - em posição central em relação às outras duas. Essas avenidas descem em direção aos fundos de vale, cortando o eixo rodoviário da cidade (Avenida Anhanguera) - formando com esta um triângulo equilátero -, e prolongando-se mais abaixo até a Avenida Paranaíba (que possui forma de arco centrado na Praça Cívica). A Avenida Couto Magalhães se estende ainda mais, alcançando a Estação Ferroviária (figura 1).

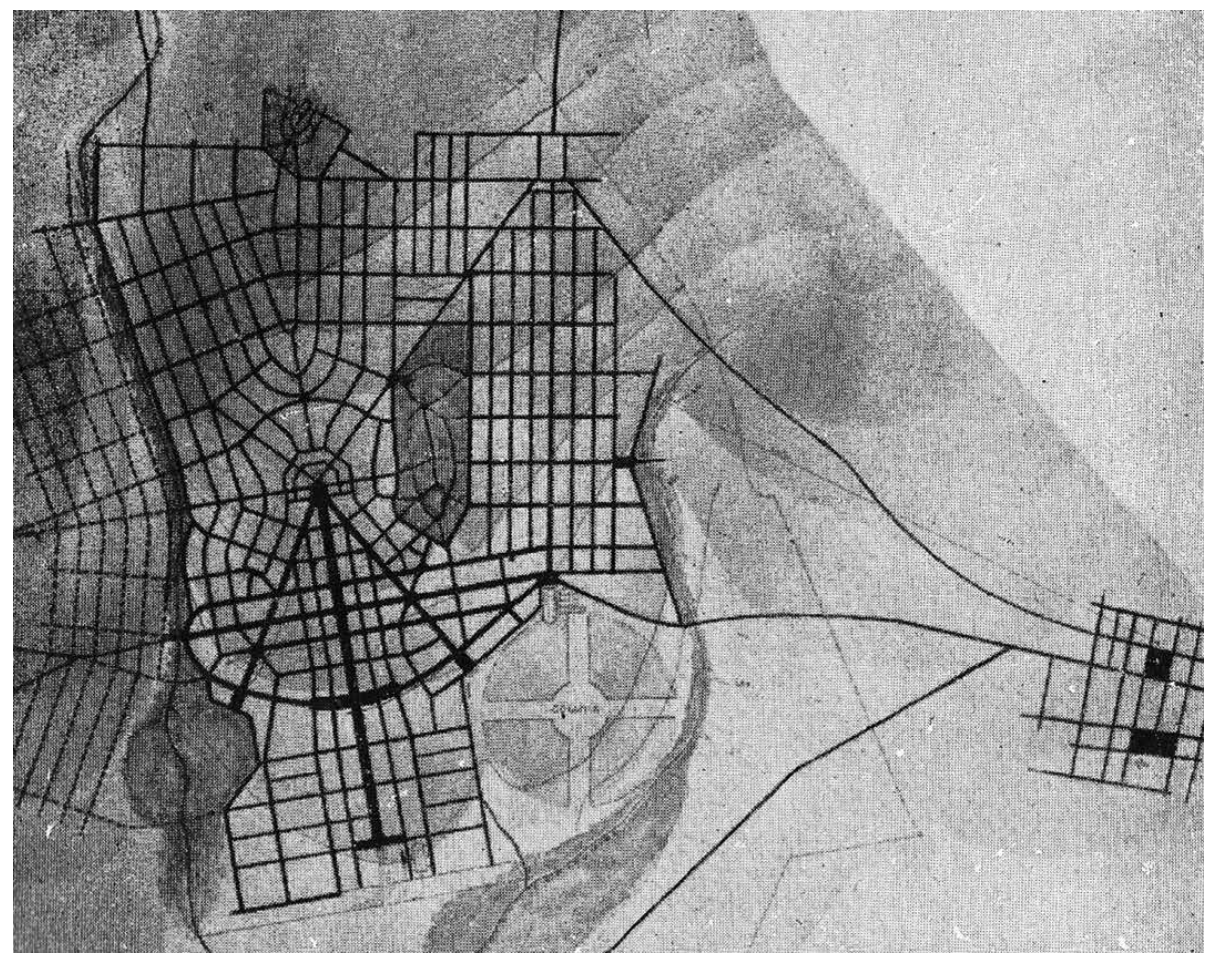

Figura 1 - Planta da Nova Capital de Goiás.

Fonte: JUNIOR, 1960.

A cidade foi dividida em zonas, e no entorno das duas avenidas principais, a Avenida Couto Magalhães e a Avenida Anhanguera, ficou definida a zona comercial-industrial. Ao redor dela, a parte destinada ao uso residencial urbano engloba todo o centro da cidade.

Attilio previu setores de expansão além do córrego Botafogo, mas o núcleo inicial de Goiânia terminava nos fundos de vale mais próximos, a leste pelo córrego Botafogo e a oeste pelo córrego Capim-puba. Estas áreas deveriam ser transformadas em parkways, respeitando sempre mais de 50 metros de área verde em cada margem do córrego, além de possuir suas matas mais frondosas preservadas como extensos parques públicos:

"[...] de preferência procuramos incluir e preservar certos sítios, já beneficiados pela natureza, para servir de parques ou jardins, evitando, tanto quanto possível, a sua destruição." 5 
O principal bosque transformado em parque (Parque do Botafogo) foi assim descrito:

"[...] é o principal parque da cidade, pela sua área de 54 ha, e pela sua vegetação luxuriante, onde medram espécies frondosas das nossas madeiras de lei. Atravessado pelo córrego de mesmo nome, que serpenteia em toda sua extensão, formando algumas corredeiras, presta-se admiravelmente para ser conservado ao natural, tirando-se partido apenas com alguns caminhos e picadas de passeio. A simples conservação da mata e uma rigorosa vigilância contra a devastação é o bastante para preservar este rico patrimônio que se encontra dentro do perímetro urbano." 6

No texto de 1937, já afastado das obras, Attilio faz referência ainda a outras áreas de igual valor, que deveriam ser preservadas da "especulação desenfreada em torno da venda das terras":

"É preciso, portanto, que desde já fiquem bem estabelecidas as reservas. Embora só muito mais tarde poderá a administração transformar essas matas em parques, nem por isso poderá dispor delas para outros fins que não os previstos." 7

Em contraste com a sugestão de preservação quase ao natural das matas mais densas próximas aos cursos d'água, ao pé da cidade, as áreas mais altas - descritas como "campina" ou "pastos extensivos" - consideradas propícias à urbanização, formam a base para o tecido urbano propriamente dito. Nestas áreas, o projeto de Goiânia previu 186 ha de espaços livres, compostos de vias públicas, jardins, praças, playgrounds, etc.. São espaços dispersos no tecido da cidade, alguns deles centrais, íntimos à vida metropolitana. São espaços de acentuada urbanidade - em alguns casos, de monumentalidade e luxo. Sobre a principal avenida da cidade, Attilio escreveu:

"A av. Pedro Ludovico tem um caráter pitoresco e monumental, constituindo uma avenida jardim. [...] [nela] só deverá ser tolerado o comércio de luxo, casas de modas, joalherias, cafés, bares e restaurantes, com instalações de gosto." 8

Os jardins da Avenida Pedro Ludovico levavam ao centro administrativo e cívico, a Praça Couto Magalhães. Esta, dando continuidade à avenida, devia se apresentar:

"Toda ela tratada com jardins baixos, à francesa (...) conterá em seu centro de simetria, um grande monumento, comemorativo da fundação do Estado, e das grandes bandeiras." 9

É notável a intenção do urbanista em unir, ainda no início da década de 1930, a beleza que viu nas matas autóctones à sua capital que tinha de Versalhes, de Carlruhe e Washington. Mas, se as matas contíguas ao tecido urbano faziam às vezes de contraponto exótico à cidade - talvez uma versão tropical dos grandes bosques parisienses - dificilmente poderiam funcionar como seu verdadeiro contexto territorial. Em verdade, 
ao acolher e ambientar a cidade, os bosques a protegem daquilo cuja perspectiva interditam: os gerais que se estendem indefinidamente ao redor da cidade, a verdade aterradora da sua dramática localização nas distâncias do interior do Brasil do início da década de 1930. Distâncias que Attilio teve de percorrer em trens, caminhões, carroças e picadas, que mediu nas próprias dificuldades de ali viver e dali comandar a implantação da capital.

E como pensar uma cidade moderna em lugar terrivelmente distante, em meio a um Cerrado muito grande, tanto maior quanto parcamente povoado, de difícil acesso e praticamente sem referências reconhecíveis para um viajante estrangeiro? A resposta de Attilio parece apontar para um redimensionamento dos horizontes de relação espacial da cidade. De fato, a opção por construir Goiânia em cota mais baixa suavizou sua exposição aos espaços de grande escala, privilegiando a ambiência local, o contato mais direto, carnal, entre a cidade e seus elementos vizinhos: os fundos de vale e os bosques. Ou seja, este reposicionamento do tecido urbano, coloca os limites de compreensão da cidade mais próximos do seu corpo construído, isolando-a e protegendo-a de relações espaciais mais amplas com um território excessivamente grande.

C confronto com o externo também se espelha, de certo modo, no próprio desenho da capital, que protege seus espaços mais vivos e íntimos do seu exterior. Com efeito, no centro de Goiânia, na Praça Couto Magalhães e nos amplos bulevares que dela partem, se previram espaços modernos, dignos de uma metrópole, ornados com jardins "à francesa". Ao seu redor, as áreas residenciais e, além delas, belas matas e cursos d'água - a serem protegidos e visitados, posto que verdadeiros parques de feitura natural - servem de limites à cidade. Da praça cívica às áreas rurais, um gradiente de urbanidade.

A localização das partes mais monumentais envoltas por áreas residenciais não permite uma relação visual com seu entorno. Suas perspectivas mais valorizadas, suas praças e avenidas (com a exceção do eixo rodoviário de ligação intermunicipal) estão enclausuradas dentro do seu próprio corpo. A Avenida Araguaia vai da Praça em direção ao Parque dos Buritis, e a Tocantins, da Praça ao Aeródromo. A Avenida Pedro Ludovico, exemplo maior, liga a Praça Cívica à gare. Aliás, o desenho da própria Praça Couto Magalhães, com os edifícios administrativos dispostos em arco oposto às avenidas citadas, evidencia o objetivo - e os limites - que a vista deveria buscar.

A tudo quanto vimos, parece ser grande a distância entre as referências notadamente clássicas de Goiânia e a realidade daquela região. Acreditamos que esta distância se reflete na separação entre os espaços mais monumentais de Goiânia e o Cerrado. Tal separação, de certo modo, conserva o significado dessas áreas de tratamento clássico e seus jardins à francesa, pois os valores ali representados esmoreceriam no contato direto com a realidade em que a capital se insere. Isto, acreditamos, assinala as dificuldades que o urbanista pode ter enfrentado em reconhecer, para além dos bosques mais próximos, uma possibilidade de paisagem para a própria criação.

Mas entre a conservação ao natural dos bosques mais frondosos do perímetro da cidade e seus jardins barrocos - alguns desenhados pelo próprio urbanista ${ }^{10}$ (figura 2) 


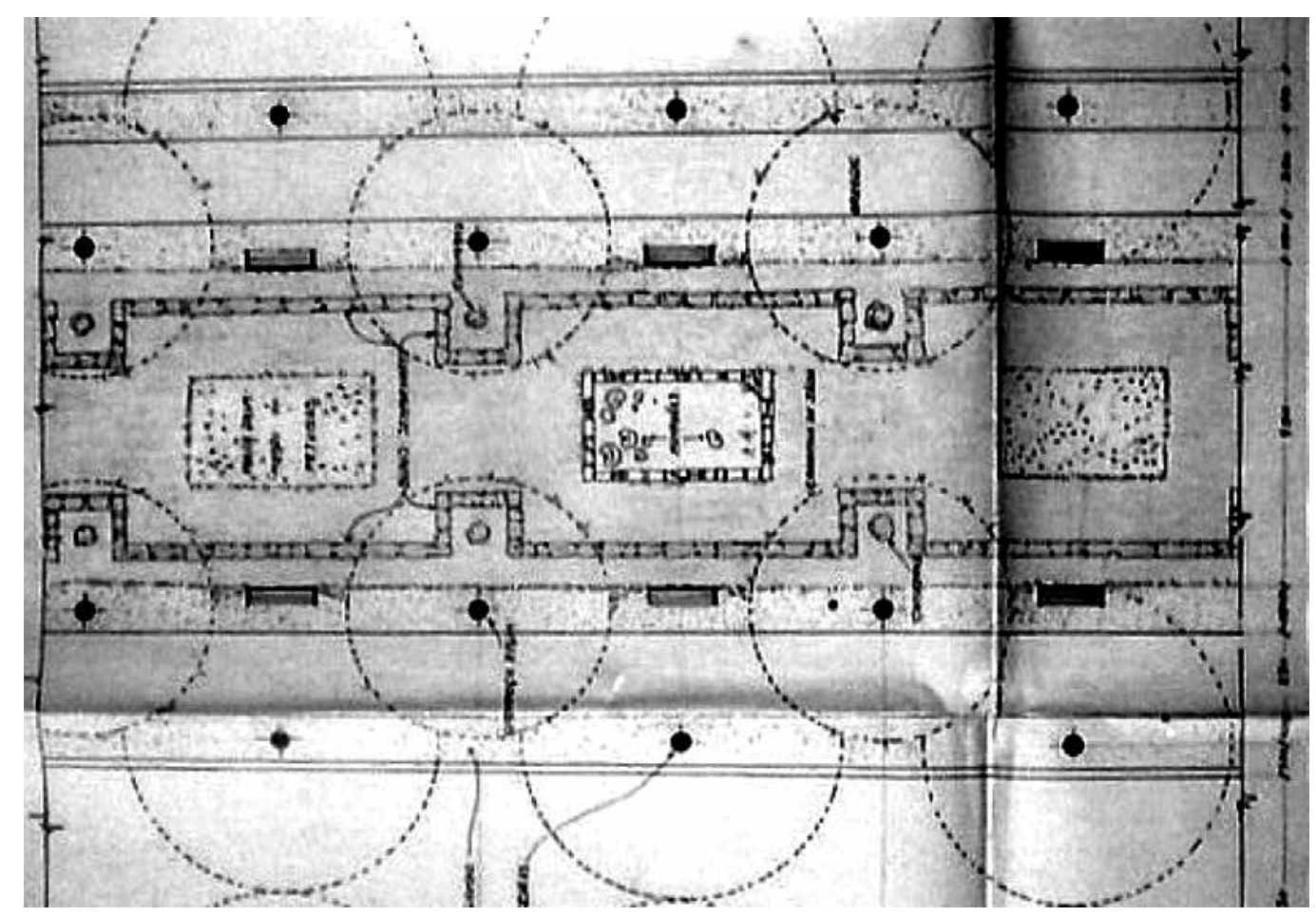

Figura 2 - Projeto para os Jardins da Avenida Goiás.

Fonte: DINIZ, 2007.

-, um parque parece sugerir uma solução de composição que incorpora um pouco daquilo que este vivenciou nos anos em que viveu e viajou por Goiás. Referimos-nos ao Parque dos Buritis, previsto por Attilio a poucas centenas de metros do centro cívico, onde havia uma vereda povoada por buritis (Mauritia flexuosa Mart.):

"O buritizal localizado na extremidade da rua 26 será transformado em pequeno parque. Para isso será necessário drená-lo convenientemente, conduzindo as águas pelo talweg, em canal descoberto, tirando partido deste para os efeitos de pequenos lagos recreativos."

Seu interesse pelo lugar ficou registrado em foto onde se encontra anotado, de próprio punho, além do nome científico da palmeira, os dizeres: "Buritizal em Goiânia, antes da construção da cidade." $\bigcirc$ reconhecimento de uma beleza com a qual ele provavelmente não era familiarizado levou-o mesmo a desenhar o parque, o que não fazia parte das atribuições originais previstas no contrato que firmara com o governo do estado"1.

Mas, se a vista da vereda original pode ter encantado o urbanista o bastante para decidi-lo a fazer um parque, que se servisse desse sítio "já beneficiado pela natureza", certamente as soluções propostas de se drenar a área, organizando suas águas em lagos, cascatas e efeitos diversos remetem mais aos tivoli franceses e aos parques americanos do começo do século que ao Cerrado. Podemos supor, de qualquer modo, que nessa 
concepção ao menos alguns elementos do Cerrado, como os buritis, permaneceriam no processo de ajardinamento do parque.

O parque dos Buritis nasce, assim, como construção algo híbrida: apresenta soluções típicas de jardins urbanos, com cascatas e lagos, não obstante tirando proveito da ambientação das majestosas palmeiras. Este é um passo além daquele que foi dado na preservação dos bosques de Goiânia, onde se tinha em vista somente a criação de passeios para o acesso e contemplação de suas belezas naturais.

Ainda que a incorporação de determinados elementos, em si, não pode nos dar prova maior da representação da paisagem do Cerrado, parece justo supor que ali Attilio encontrou um motivo para o parque, e que procurou preservá-lo em alguma medida no projeto. E isto significa dizer que aquela representação "jardinística" da paisagem procurou promover, além de valores variados, ligados aos parques e jardins urbanos, certa ligação com a natureza autóctone de Goiás.

Acreditamos que o Parque dos Buritis é, assim, no plano de Goiânia, a margem de intersecção entre a vivência do Cerrado e as referências estéticas importadas da capital. Contudo, como vimos, esse impulso não foi suficientemente importante para promover uma organização "paisagística" entre a cidade e seu território. Não podemos afirmar, com efeito, que o plano original de Goiânia propõe ou representa o Cerrado como paisagem. Mais justo seria dizer que o Cerrado permaneceu excluído, não só dos seus espaços livres centrais, mas também dos horizontes da cidade.

\subsection{Brasília}

Lúcio Costa desenvolveu sozinho a proposta que submeteu ao "Concurso Nacional do Plano Piloto da Nova Capital do Brasil", durante os poucos meses entre a publicação do edital do concurso - em 19 de setembro de 1956 - e a data limite para a entrega, de 11 de março de 1957. A apresentação sumária do plano lhe custou a censura de outros concorrentes, mas não impediu que tivesse a melhor avaliação entre os membros do júri.

Para o desenvolvimento do plano, o arquiteto dispunha, por certo, dos documentos disponibilizados pela "Comissão de Planejamento da Construção e da Mudança da Capital Federal", que incluíam mosaico aerofotográfico na escala 1:50.000 de todo o distrito federal e, especificamente, sobre o sítio escolhido para a construção de Brasília, mapas topográficos com curvas de nível de metro em metro e a cota alagada do lago Paranoá $^{12}$ São justamente a topografia e o desenho do lago que centram os vetores do traço inicial, o gesto primário da Cruz.

Na planta entregue por Lúcio Costa, o plano ocupa uma área aproximadamente triangular, com um dos vértices encaixado entre os braços da margem oeste do lago Paranoá (figura 3). Dentro desse espaço, o eixo monumental deita-se sobre um espigão que vai do lago em direção ao cume de uma colina suave, onde deveria ser construída uma torre radioemissora, chegando depois até a rodovia que ligaria a capital a Anápolis e Patrocínio, que delimita o lado oeste da área triangular citada.

O eixo rodoviário corta o eixo monumental na perpendicular, abrindo-se em duas asas simétricas (norte e sul), praticamente planas e arqueadas a oeste, acompanhando 


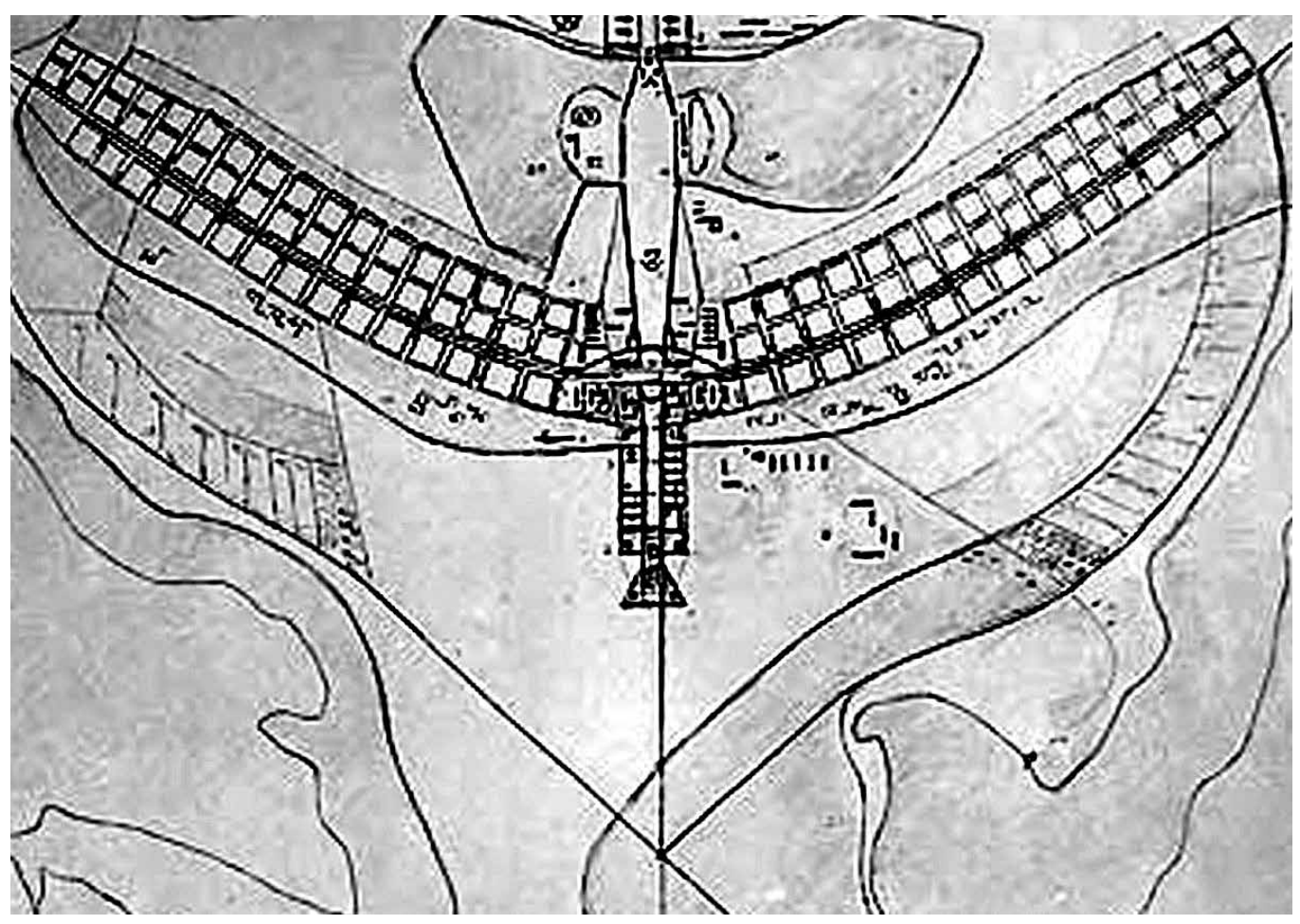

Figura 3 - Original do Plano Piloto de Brasília. Fonte: LEITÃO, 2009

o desenho do lago Paranoá. Essa primeira ossatura da cidade mostra uma conformação que se delineia também a partir dos aspectos físicos do sítio escolhido, não por acaso, para a construção da nova capital ${ }^{13}$

$\mathrm{Na}$ "Memória Descritiva do Plano Piloto" o arquiteto apresenta as partes componentes da sua cidade, começando por seus dois eixos principais. As relações espaciais entre a topografia e a arquitetura atuam como princípio norteador da descrição da parte principal do eixo monumental ${ }^{14}$ :

“Destacam-se, no conjunto, os edifícios destinados aos poderes [...] [sobre] um terrapleno triangular, com arrimo de pedra à vista, sobrelevado na campina circunvizinha [...]. Em cada ângulo dessa praça — PRAÇA DOS TRÊS PODERES - localizou-se uma das casas, ficando as do Governo e do Supremo Tribunal na base, a do Congresso no vértice, com frente igualmente para uma esplanada ampla, disposta num segundo terrapleno, de forma retangular e nível mais alto, de acordo com a topografia local, igualmente arrimado de pedras em todo o seu perímetro. A aplicação, em termos atuais, dessa técnica oriental milenar dos terraplenos garante a coesão do conjunto e lhe confere uma ênfase monumental imprevista. Ao longo dessa esplanada - o Mall dos ingleses, extenso gramado destinado a pedestres, a paradas e a desfiles, foram dispostos os ministérios e autarquias. [...] A Catedral ficou igualmente localizada nessa esplanada, mas numa praça autônoma disposta lateralmente, não só por questão de protocolo [...] [mas] principalmente por outra 
razão de ordem arquitetônica: a perspectiva de conjunto da esplanada deve prosseguir desimpedida até além da plataforma, onde os dois eixos se cruzam."

Domina o conjunto, a oeste, a "[...] torre monumental das estações radioemissoras e de televisão tratada como elemento plástico integrado na composição geral".

Do cruzamento em desnível do eixo monumental com o eixo residencial-rodoviário, sobre a rodoviária ou do centro de diversões próximo a ela - em meio a enormes luminosos de reclame, restaurantes com paredes envidraçadas, cafés sobre arcadas "(mistura, em termos adequados, de Piccadilly Circus, Times Square e Champs Elysées)" -, se abriria a vista da esplanada, de um lado, e da torre, do outro, num ambiente "adequado ao convívio e à expansão", centro "gregário" da capital.

Na parte residencial, a opção por grandes quadras (as superquadras) perfiladas em torno dos braços do eixo rodoviário, "concilia a escala monumental, inerente à parte administrativa, com a escala menor, íntima, das áreas residenciais".

Seriam quadras de 300 por 300 metros, compostas por "prédios soltos do chão sobre pilotis, no gabarito médio das cidades européias tradicionais - antes do elevador -, harmoniosas, humanas, tudo relacionado com a vida cotidiana; as crianças brincando à vontade ao alcance do chamado das mães" ${ }^{15}$. Essas superquadras se queriam "emolduradas por uma larga cinta densamente arborizada, árvores de porte, prevalecendo em cada quadra determinada espécie vegetal, com chão gramado e uma cortina suplementar intermitente de arbustos e folhagens", para resguardar seu interior, amortecer o impacto visual dos edifícios e garantir a ordenação urbanística da sequência de superquadras.

Faixas mais ao externo das superquadras garantiriam a coesão do tecido urbano e a transição para o espaço não ocupado pela cidade. Do lado oeste, as superquadras faziam fundo com uma via de serviços seguida por "uma faixa de terreno equivalente a uma terceira ordem de quadras para floricultura, horta e pomar". Do lado leste, depois da via de serviços contígua às superquadras, estava o setor de embaixadas, de baixa densidade de edifícios envoltos por áreas verdes muito provavelmente ajardinadas e arborizadas. Depois das embaixadas, uma alameda arrematava o conjunto, e dali, ao se olhar em direção ao lago, ter-se-ia "a vista desimpedida sobre a paisagem, excetuando-se o hotel principal localizado nesse setor e próximo do centro da cidade".

Alguns setores residenciais foram ainda previstos à parte do conjunto constitutivo das asas, localizados próximos à orla do lago:

"Previram-se igualmente setores ilhados, cercados de arvoredo e de campo, destinados a loteamento para casas individuais, sugerindo-se uma disposição dentada em cremalheira para que as casas construídas nos lotes do topo se destaquem na paisagem [...]. E admitiu-se igualmente a construção eventual de casas avulsas isoladas, de alto padrão arquitetônico - o que não implica tamanho - estabelecendo-se, porém, como regra, nestes casos, o afastamento mínimo de um quilômetro de casa a casa, o que acentuará o caráter excepcional dessas concessões." 
Sobre a orla do lago, o arquiteto decidiu por "preservá-la intata, tratada com bosques e campos de feição naturalista e rústica para os passeios e amenidades bucólicas de toda a população urbana". Apenas construções específicas, como o Palácio da Alvorada, o hotel e a cidade universitária seriam ali permitidas, entremeadas por bosques que iriam até a margem da represa, "bordejada nesse trecho pela alameda de contorno que intermitentemente se desprende da sua orla para embrenhar-se pelo campo que se pretende eventualmente florido e manchado de arvoredo".

Brasília é, para Lúcio Costa, "deliberadamente aberta aos 360 graus do horizonte que a circunda", e incorpora o "imenso céu do planalto, como parte integrante e onipresente da própria concepção urbana"16 Disso dão testemunho várias das passagens citadas acima, da Memória Descritiva do Plano Piloto e de outros documentos do próprio Lúcio Costa ${ }^{17}$.

A abertura de Brasília ao horizonte beneficia-se da posição topográfica do sítio escolhido para a construção da capital. De fato, o projeto de Brasília tira proveito da topografia e estabelece relações espaciais privilegiadas com seu entorno, notadamente como suporte para assinalar a monumentalidade de sua parte administrativa. A cuidadosa relação de perspectivas que se abrem no eixo monumental, como vimos nas passagens do Memorial citadas acima, é potencializada justamente pela sua posição de crina. Essa posição de domínio do entorno explorada pelo plano, poderíamos dizer, serve como indício de relações espaciais de caráter amplo, que mobilizam a percepção das distâncias do país inteiro.

Eis aí uma diferença notável em relação à Goiânia. A amplidão do interior do Brasil, na capital de Lúcio Costa, não constitui ameaça. Antes, situa a capital como centro do território nacional e dá-lhe relevo. Brasília não se perde na profundidade do Cerrado, antes o contrário: toma posse do interior do Brasil. Essa é a potência subjetiva do seu horizonte: o domínio de todo o Planalto Central.

Este domínio do território numa escala tão ampla é possibilitado pela ideia de todo o Planalto Central como um vazio imenso, de "deserto a perder de vista"18. Um tal vazio, que parece reforçar a amplidão do espaço, se reflete na invocação ao céu. É a esse espaço, vasto e deserto, representado pelo próprio céu, que se abre Brasília. Nele sobressai sua monumentalidade.

Esta ideia de vazio imenso nos convida à percepção do contexto territorial mais amplo, a que o plano de Brasília responde. Ele encontra eco nos seus espaços abertos - desde o conjunto da Esplanada dos Ministérios, os grandes eixos viários, até os gramados contínuos, em meio aos blocos sobre pilotis das superquadras.

A organização dos espaços residenciais da capital reflete a concepção da sua parte mais central, com superquadras "apenas niveladas [...], sem calçamento de qualquer espécie nem meios-fios" nas vias tratadas "como caminhos de parque"19 e grandes blocos de apartamentos horizontais dispostos num gramado amplo. Mas, por constituírem espaços dedicados à vida mais íntima da população, estes parques, como vimos, se queriam protegidos por renques uniformes de grandes árvores em seu perímetro (figura 4). 


\section{SETOR RESIDENCIAL}

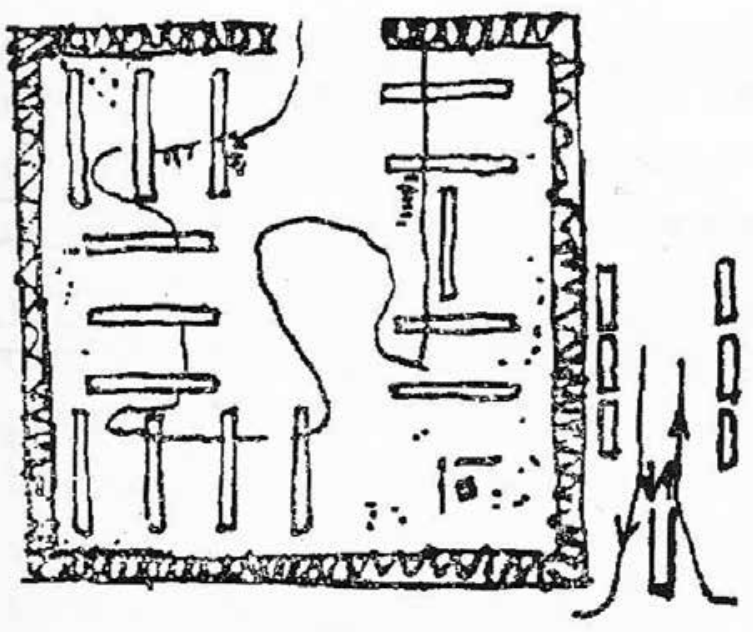

Figura 4: Superquadras - Memorial do Plano

Piloto de Brasília

Fonte: COSTA, 1995

Essas árvores, queremos ressaltar, protegem o interior das superquadras dos abertos, não somente intraurbanos, como o do amplo tapete de asfalto e gramado do eixo rodoviário-residencial ${ }^{20}$, mas, também, e principalmente do vazio do território além da cidade. Neste sentido, a proteção do tecido residencial é complementada pelas faixas de horticultura e pomar a oeste; e o setor de embaixadas a leste. Assim, "o ritmo e a harmonia dos espaços urbanos se faz sentir na passagem, sem transição, do ocupado para o não-ocupado - em lugar de muralhas, a cidade se propôs delimitada por áreas livres arborizadas" 21

A tensão exterior-interior, que opõe a amplidão da paisagem à ideia de pátios delimitados, dá relevo ao aconchego e à intimidade dos espaços residenciais. Dentro deles, os grandes blocos horizontais continuam a lembrar e promover Brasília como uma cidade monumental, aberta a um vasto território, para o qual, com efeito, os apartamentos mais altos permitem uma vista privilegiada.

No entanto, a solução de gramados e arborização densa se distancia da impressão da constituição da natureza do interior do Brasil. De fato, essas áreas, assim como outras mais dedicadas à fruição, privilegiaram soluções paisagísticas que lembrariam mais parques urbanos à inglesa, entremeando bosques e gramados. E elas reaparecem em outras áreas descritas no plano como o Jardim Botânico e o Jardim Zoológico, "constituindo essas duas imensas áreas verdes, simetricamente dispostas em relação ao eixo monumental, como que pulmões de nova cidade"; os cemitérios, com "chão de grama e [...] convenientemente arborizados, com sepulturas rasas e lápides singelas, à maneira inglesa", o setor de residências individuais entre as asas e o lago, "cercado de arvoredo e de campo", e a orla do lago, "tratada com bosques e campos de feição naturalista e rústica", onde os poucos edifícios permitidos seriam "entremeados por denso bosque que 
se estende até a margem da represa, bordejada nesse trecho pela alameda de contorno que intermitentemente se desprende da sua orla para embrenhar-se pelo campo que se pretende eventualmente florido e manchado de arvoredo".

No mapa do Plano Piloto submetido ao concurso, as áreas citadas acima foram coloridas na cor verde. As menções aos campos "de feição naturalística e rústica", "eventualmente floridos e manchados por arvoredo", dificilmente poderiam representar a incorporação da vegetação nativa do cerrado - que não vem mencionado no memorial descritivo - no contexto bucólico da capital. Em todos esses casos, contudo, os gramados abertos e o uso de árvores mais frondosas em formações densas parecem deixar, aos olhos do arquiteto, essas áreas mais aprazíveis - e mais distantes dos campos originais daquela região.

No mapa do Plano Piloto, a área ao redor de toda a Esplanada dos Ministérios e da Praça dos Três Poderes permanece em branco, como indicação de que ali a vegetação nativa seria mantida intacta. Sobre essa área, o eixo monumental da cidade projeta-se deliberadamente para fora do tecido urbano, sobrelevado em terrapleno que chega a atingir 5 metros de altura. Nas palavras do próprio Lúcio Costa:

"O normal seria o centro envolvido pela área urbana. Mas na concepção de Brasília, ele foi levado ao extremo da composição urbanística da cidade [...] [com] o objetivo de acentuar o contraste da parte civilizada, de comando do País, com a natureza agreste do cerrado... O cerrado representaria o povo, a massa de gente sofrida, que estaria ali junto ao poder da democracia que lhe é oferecido." 22

A mobilização do Cerrado no Plano Piloto vem evidenciada justamente no contato do ponto mais simbólico da capital com a natureza do Planalto Central. Se a monumentalidade de Brasília se apoia na vastidão de seu horizonte, sua modernidade se torna mais contundente contra a "natureza agreste".

É a esse território que se abre Brasília: uma significação de vastidão que the realça a razão e a monumentalidade. Uma realidade agreste vivenciada como estrutura e cenário de seus conjuntos mais simbólicos e modernos - e da qual a vida cotidiana, representada nas zonas residenciais, deve ser protegida.

O problema que afligia Attilio, por ocasião da construção da capital para o distante e atrasado estado de Goiás, nos anos 1930, para Lúcio Costa, em 1957, se coloca como oportunidade para a capital de um grande país em pleno desenvolvimento. Brasília, como vimos, se abre e se apropria do Cerrado: de suas enormes distâncias e de seu aspecto árido. Mas se é verdade que Brasília se abre ao território, resta ainda saber se o mesmo se apresenta enquanto paisagem viva, ou traduzido em valores já fixados, distantes de uma experimentação estética daquela natureza que o autor poderia ter encontrado, se não in situ, em representações artísticas, onde a paisagem de Cerrado se faz apreender ainda viva e pulsante. Para buscar responder, ainda que de maneira sucinta, a esta questão, tratemos daquelas ideias relacionadas ao território, às quais o Plano Piloto parece se referenciar: 
A ideia de vastidão, de deserto a perder de vista, como procuramos expor acima, transparece no desenho da cidade. Brasília, como a viu Lúcio Costa, é uma cidade aberta, com efeito, a um horizonte imenso. Desta imensidão se apropria a cidade, realçando a monumentalidade de seu partido urbanístico. Essa ideia certamente concorre para a magnitude atingida pela proposta de Lúcio Costa. Mas convém perguntar o quanto ela pode ainda resguardar de uma estética da imensidão, construída diretamente pela imersão no Cerrado.

É nossa opinião que, ao elevar a potência do olhar à magnitude em que este, objetiva e subjetivamente, apresenta em Brasília, esta ideia resta excessivamente límpida, descarnada de um sentimento mais vivo de imensidão sentida de dentro do Cerrado, imensidão sofrida, como a sofreu Attilio. Assim, perde-se o gosto próprio da paisagem que se dá a ver, pois a ele se sobrepõe um conceito. Com efeito, ainda que a vista domine grandes extensões, ao rés do chão, o Cerrado pode não se apresentar tão cristalino. Enfim, a percepção do Cerrado como um vazio imenso parece estar calcada numa perspectiva demasiado ampla, demasiado distante das tonalidades de uma experiência de imersão nesta paisagem.

O território a que se abre Brasília, contudo, não é amplidão simplesmente. Ele é agreste, tal qual o arquiteto o apresenta no entorno da Praça dos Três Poderes. Esta ambientação do conjunto principal da cidade pela vegetação nativa dá cor à amplidão a que se abre Brasília. Mas note-se: se a ideia de vastidão encontra-se no próprio corpo da cidade, a "natureza agreste" é incorporada apenas como cenário, sua impressão estética não está nele (no corpo da cidade) representada. Antes, serve-lhe de contraponto. Permanecem estanques, no campo das representações, os dois polos: a natureza autóctone e a capital moderna.

\subsection{Palmas}

Em dezembro de 1988, ainda antes de tomar posse como primeiro governador do recém-criado Estado do Tocantins, José Wilson Siqueira Campos já se tinha decidido por construir uma nova cidade para sediar a capital no centro geográfico do estado. Para tanto, convidou o arquiteto Luiz Fernando Cruvinel Teixeira - que se associou ao arquiteto Walfredo Antunes de Oliveira Filho - para coordenar a "Comissão Especial de Estudos da Nova Capital", com o objetivo de selecionar um sítio adequado para construir Palmas ${ }^{23}$ No dia 15 de janeiro de 1989, o governador e os arquitetos contratados fizeram o primeiro sobrevôo para o levantamento dos sítios mais propícios, que seriam depois melhor estudados pela comissão técnica ${ }^{24}$

A comissão coordenada pelos arquitetos apontou inicialmente quatro sítios aptos: Mangues, Carmo, Santa Luzia e Canela. Estes foram então comparados entre si por critérios técnicos como topografia, disponibilidade de água para abastecimento e facilidade de acesso. Dentre os classificados - Mangues e Canela - a comissão optou pelo primeiro, principalmente por estar na mesma margem do Rio Tocantins que a rodovia Belém-Brasília (BR 153). $\bigcirc$ governador, no entanto, requisitou aos arquitetos que revertessem a decisão em favor da localidade Canela: 
"Ele falou assim: 'O trabalho é muito bom, mas você vai mudar o ranqueamento da Mangues, com Canela.' [...] 'No Tocantins tudo foi construído na margem esquerda: Belém-Brasília, cidades, tudo. A margem direita não tem nada, só deserto." 25

Os arquitetos acataram a decisão do governador e, durante a apresentação dos levantamentos técnicos, no dia 28 de janeiro, Canela foi defendida também por Luiz Fernando mesmo em desacordo com o próprio relatório - pelas características extraordinárias do sítio:

"No dia da apresentação eu disse: 'Vou começar esse filme pelo fim; se me fosse dado o direito de escolher eu escolheria a área número dois [Canela]. [A área Mangues] é a mais técnica, seria pra uma cidade mais eficiente. Mas a da direita é a mais bonita.' [...] 'A cidade aqui no Mangues vai ser uma cidade comum. Em Canela vai ter uma serra como pano de fundo e um lago do outro lado. Qual cidade no mundo tem isso?'." 26

A escolha final da localidade cabia à Comissão da Assembléia Estadual, que referendou a decisão por Canela no dia 09 de fevereiro de 1989, quando teve início o planejamento da cidade.

Posteriormente foi definida pelos arquitetos a "Área de Urbanização" na margem direita do rio Tocantins, que consistia numa faixa de declividade suave entre a Serra do Lajeado e o espelho da futura "Represa do Lageado" (formada pela Usina Hidrelétrica Luiz Eduardo Magalhães, cuja construção já estava definida anteriormente).

O Plano de Palmas foi publicamente apresentado pelos arquitetos no dia 20 de maio de 1989, decorridos apenas pouco mais de três meses da sua contratação. Também nesta etapa houve ingerência de Siqueira Campos, e ao se analisar o plano de Palmas não se pode deixar de considerar as suas intromissões na locação de importantes elementos do desenho urbano, notadamente o palácio do governo e a avenida principal que lhe deveria dar importância 27 e 28

No plano apresentado, a Avenida Principal (Avenida Teotônio Segurado, hoje "Avenida Governador Siqueira Campos"), corta no sentido norte-sul, centralizada entre a serra e a represa, toda a Área de Urbanização. Seria este o eixo mais importante, a "espinha dorsal" da urbanização, com 150 metros de largura total e uma faixa verde central de 40 metros de largura, "cuja arborização abundante deverá humanizar o impacto do sol do centro-oeste nas pistas asfaltadas" 29 . Paralelas à avenida principal, e nos limites da área a ser urbanizada, foram previstas a Avenida Parque, a oeste, seguindo os contornos da represa, e a Perimetral Leste, junto à Serra do Lajeado.

A avenida principal se cruza perpendicularmente com o eixo leste-oeste (Avenida Juscelino Kubitschek), que vai da serra até a represa, para onde se previu a construção de uma futura ponte suspensa. No cruzamento entre essas duas avenidas está localizada a Praça dos Girassóis, no alto de uma pequena colina, onde a quis o governador (figura 5).

Os eixos longitudinais de Palmas cruzam os cursos d'água que descem da serra em direção ao Rio Tocantins. Em torno deles, o projeto previu parques lineares, delimitados 


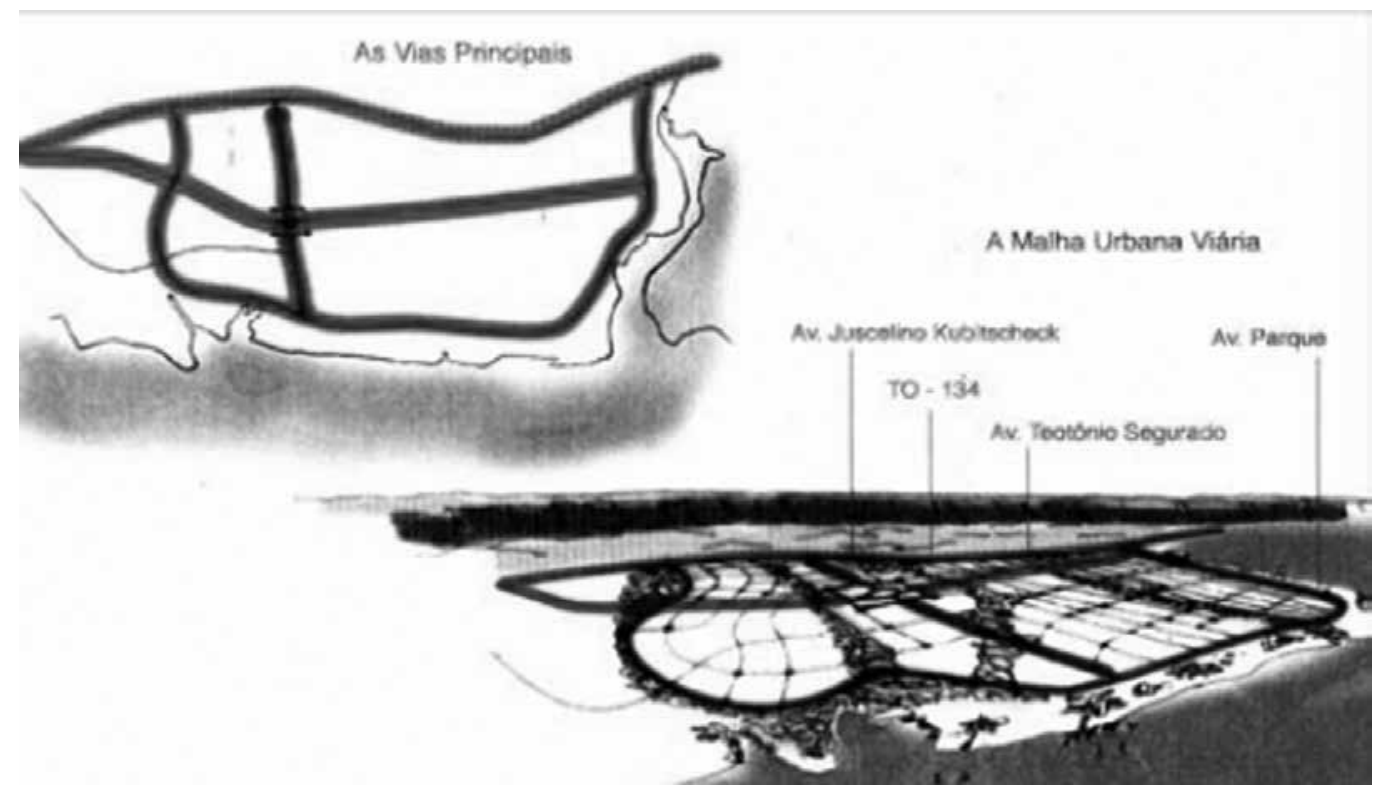

Figura 5 - Croquis do plano de Palmas

Fonte: GRUPOQUATRO S/C

por "vias de fundo de vale", que "sugerem uma relação constante entre os habitantes e os parques lineares". Nestas áreas verdes, "escolas, pequenos centros culturais e outros que necessitem de espaços verdes e cuidem de preservá-los".

Vias secundárias formam um quadriculado ortogonal adaptado às curvas da orla do lago e à interferência dos fundos de vale. $\bigcirc$ desenho do traçado proposto deve-se principalmente à praticidade e à busca de redução de custos na implantação da cidade. Essa escolha respondeu também à melhor circulação dos ventos e, segundo o autor, ainda "tinha como princípio [permitir] a vista da serra e do lago. Isto é, quando se vai para o leste se vê a serra, e quando se vai para o oeste, o lago" 30

Essa malha viária delimitou "grandes quadras" residenciais com cerca de 700 por 700 metros de lado, isoladas das vias arteriais e com trânsito apenas local. Para tais quadras não foram previstas cintas arborizadas, gabarito ou desenho específico para a urbanização: "Democraticamente, poderão ter expressões arquitetônicas individualizadas, com recantos e bosques que deverão regular a boa composição final." Alguns croquis exemplificativos indicavam, de toda forma, certa centralidade dos equipamentos urbanos, como creches, postos de saúde e praças. Ao seu redor, edifícios residenciais de gabaritos variados, incluindo residências unifamiliares e geminadas. $\bigcirc$ plano básico fixou somente a densidade populacional em 300 hab./ha ("1.600 famílias por quadra") e o percentual de $15 \%$ de áreas verdes:

"A gente imaginou que aqui dentro [das grandes quadras] você teria uma cidadela de oito a dez mil habitantes, que fora dela é uma cidade moderna, com 
avenidas largas. [...] Brasília tem superquadras construídas, aqui não, aqui é uma cidadela com lote, com prédio, com comércio." 31

Na linha do eixo principal se reúnem os setores de serviços ("Vamos imaginar las avenidas] L2, a W3, a W4 e a W5, onde fica aquela série de escolas, igrejas, lojas, hospitais, clínicas, clubes, e imagine tudo isso no eixão de Brasília." ${ }^{32}$ ) e dois parques urbanos foram previstos onde a avenida principal cruza os cursos d'água. Estes parques urbanos seriam, portanto, integrados aos parques lineares de fundo de vale da cidade.

Ao leste da rodovia estadual, a área situada entre a cidade e a Serra do Lajeado foi declarada Parque Ecológico, perfazendo 1.000 hectares e "valorizando a vegetação existente". Dentro do parque, o Jardim Botânico (destinado ao "cultivo e estudo das plantas nativas, particularmente as do cerrado", ao lazer e às atividades didáticas) e o Zoológico.

Ao oeste da cidade, a Avenida Parque guarda uma distância de aproximadamente 400 metros da orla da represa. Esta faixa "permite a instalação dos equipamentos que caracterizem o aspecto de transição entre a cidade e o futuro lago", constituindo lugar adequado para "clínicas, clubes, escolas maiores e a universidade" 33 Além desta faixa, o grande espelho do lago, que ainda não existia.

O desenho da malha urbana de Palmas atesta a criação de uma cidade a partir das conformações do sítio visitado, como se os arquitetos começassem o projeto justamente pelo mapeamento dos elementos preexistentes:

"Então, quais foram os elementos que determinaram o desenho dessa cidade? Primeiro a Serra. Segundo, uma área entre a cidade e a Serra que queríamos considerar como o Parque, [...] com preservação da natureza. Depois, os rios que nasciam na Serra. E, finalmente, o lago que era algo construído. Quando você pega esse desenho, é o desenho da cidade de Palmas.." ${ }^{14}$

Aí se apresenta o ponto de partida da nossa reflexão: a participação dos arquitetos na escolha do sítio para a construção de Palmas, com os métodos de reconhecimento do território de que fizeram uso, incluindo as mais de 40 horas de sobrevôo em helicóptero, incursões por terra e fotos de satélite ${ }^{35}$, parece ter dado a Palmas sua principal motivação. $\bigcirc$ memorial do plano de Palmas ressalta esse motivo e, efetivamente, o desenho da cidade o comprova.

Este reconhecimento do sítio, contudo, poderia ganhar em relevância exatamente quando os elementos citados, a serra, os fundos de vale, o lago (a expectativa do lago), todos eles se animassem, ganhando unidade de significado independente, outra que a simples soma dos elementos naturais do sítio onde se inserirá a cidade. Uma passagem do memorial parece justamente tentar compor para o leitor uma visão daquele lugar em chave paisagística:

"Os vapores das nascentes da sinuosa Serra do Lajeado e do curso do Tocantins se fundem em nuvens, de cuja integração da energia positiva, emanada 
das águas correntes, com a massa calma do plano de água da futura represa do Lajeado sobressaem os terrenos da cidade."

Se Palmas foi desenhada a partir do sítio, o memorial busca nele verdadeiro acoIhimento num vislumbre de paisagem. A citação acima parece fazer referência ao olhar que aprecia das alturas as terras da capital, que contempla a grandiosidade da serra, a sinuosidade dos cursos d'água, os recantos mais planos. Um olhar que reúne numa só visada a peculiaridade do sítio escolhido ${ }^{36}$ Essa visada delimita o sítio de Palmas e o destaca do contexto geral de território. Proporciona à cidade - assim o querem seus autores - genuína vantagem. A cristalização dessa unidade é o primeiro ponto que queremos ressaltar.

Neste trabalho, entretanto, interessa interrogar como essa paisagem aparece no plano, para além da conformação direta de seu tecido pela realidade topográfica e pelos corpos d'água. Interessa-nos saber se a cidade estrutura uma relação de cunho paisagístico com o território e se este vem representado enquanto paisagem em seu plano. Para tanto, parece mais relevante o caso do eixo principal de Palmas.

A Avenida Teotônio Segurado, com seus 150 metros de secção transversal, funciona como elemento central no desenho da cidade - nela se encontram o centro comercial e administrativo. A interferência da Praça dos Girassóis, no desenho da avenida principal, a quanto consta, não pode ser imputada aos arquitetos. De qualquer modo, nota-se que sua posição dominante, no alto de uma colina, interfere drasticamente na continuidade do traçado do eixo principal ${ }^{37}$ (figura 6).

Esta avenida queria-se "densamente arborizada" - tendo em vista as condições climáticas - divergindo do amplo plano gramado pretendido por Lúcio Costa. Por

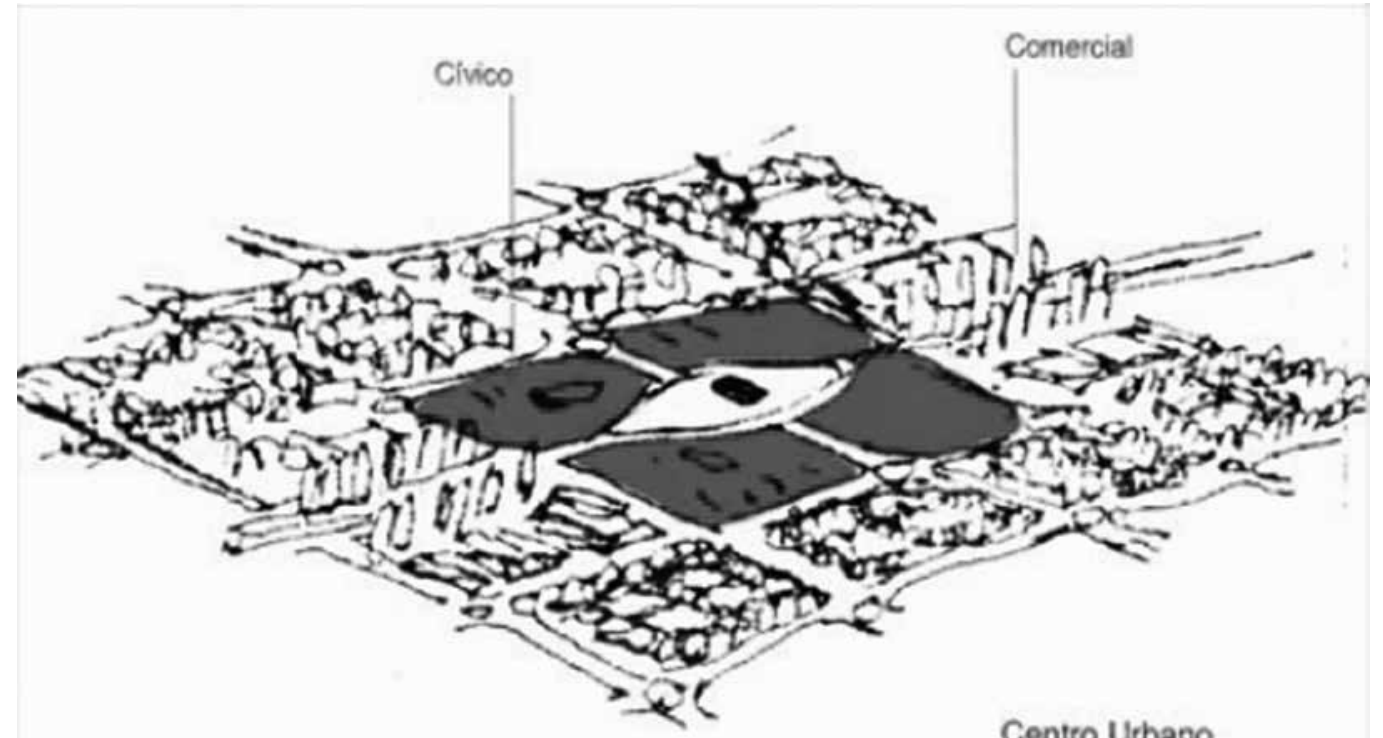

Figura 6 - Croqui Praça dos Girassóis Fonte: GRUPOQUATRO S/C 
muito que se deva levar em conta os aspectos práticos desta configuração, é preciso reconhecer que ela altera completamente a percepção do espaço e da cidade. De qualquer modo, por "arborização densa" não compreendemos um ajardinamento que privilegie a organização de perspectivas ou a proposição de ambiências baseadas em um plantio de árvores mais criterioso.

As quadras que estão contíguas à avenida também não tiveram seu conjunto melhor definido, Os arquitetos decidiram-se por não estabelecer um gabarito para os edifícios no interior das quadras, nem uma organização dos espaços no interior das mesmas ou tratamento especial para seu perímetro. Sendo assim, a largura avantajada da avenida principal - como também dos principais eixos de circulação - em Palmas, não parece espelhar a organização das perspectivas para quem transita naquelas vias.

A disposição da avenida principal, paralela à Serra do Lajeado e à orla da represa, também não privilegia a perspectiva desses elementos. Ocorre, em verdade, certa independência do conjunto principal e mais simbólico da cidade em relação ao seu sítio. Um indício pontual disto é o edifício do palácio do governo, que fica centralizado em relação ao eixo principal e à Avenida Juscelino Kubitschek, de sentido leste-oeste. Este edifício, ao invés de se voltar para o eixo que vai do lago à serra, e então ter sua perspectiva apoiada na grandiosidade dos marcos naturais, dá a preferência de sua melhor fachada à avenida principal.

A Avenida Juscelino Kubitschek é o principal eixo transversal de Palmas. Contudo, seu traçado não difere substancialmente das demais vias arteriais de Palmas, sendo interrompido a intervalos regulares por rotatórias. A vista da serra e do lago resta ainda mais prejudicada no que seria o principal eixo leste-oeste pela interferência da Praça dos Girassóis, que a divide em dois tratos praticamente independentes. Com efeito, a Praça dos Girassóis se impôs como motivo principal não só da Avenida Norte-Sul quanto da Leste-Oeste, conquanto esta última abra caminho à serra e ao espelho $d^{\prime}$ água. Isto fica ainda mais ressaltado porque o desenho destas avenidas não parece ter proposto outras referências visuais que não a da praça principal.

O tecido residencial da capital também não parece delinear maiores relações com o sítio que a própria pertença e proximidade. A malha externa das "grandes quadras" é homogênea e privilegia a lógica de implantação e funcionamento da capital. As quadras em si não foram mais bem definidas, mas, em passagem citada acima, foram descritas como pequenos núcleos relativamente autônomos para a vida cotidiana, nos moldes de "uma cidadela de oito a dez mil habitantes". Nos desenhos apresentados pelos arquitetos, seus espaços livres parecem referenciados unicamente pela constituição de um núcleo central para estas "cidadelas" isoladas.

Sem organizar uma relação autenticamente visual com o entorno, as ligações mais fortes com o sítio são, em Palmas, do signo da fruição e da integração, temas recorrentes no seu Plano Original. Catalisadores desta relação são o Parque Ecológico, a faixa protegida à orla do lago e os parques lineares: lugares que propõem a integração da natureza ao corpo e à vida da cidade: 
“Na cidade que será criada como a Capital do Tocantins existem condições favoráveis para incorporar o verde em sua realidade, permitindo integrá-lo de maneira harmônica à paisagem urbana e garantir a necessária integração entre o homem e a natureza."

Se o desenho de Palmas não desenvolve uma apropriação paisagística do território, seu memorial busca ressaltar a proposta de uma integração à natureza. Uma integração que abdica de estabelecer uma relação estética com a natureza da região, conservando apenas a vantagem da pertença àquele contexto privilegiado. Ou seja, se a paisagem, aos olhos dos arquitetos, pode eventualmente cristaliza-se a partir daquele sítio privilegiado, tal como comparece na retórica do Plano Original, nas contingências do planejamento da capital ela volta a dissolver-se em natureza.

O plano de Palmas, tampouco, parece desenvolver representações do Cerrado. Em verdade, a descrição sumária do partido da cidade se abstém de delinear a construção e o caráter de seus espaços urbanos. Nota-se, também aqui, a proposta dominante de proteger e integrar o tecido urbano à natureza preservada. Neste sentido podemos comparar as áreas verdes previstas em Palmas com aquelas do Parque do Botafogo, de Goiânia, onde a natureza se integra ao conjunto urbano integralmente, sem receber o crivo do processo de apropriação e representação que confirmariam seu status de paisagem.

\section{CONCLUSÃO}

A construção de novas capitais - Goiânia, Brasília e Palmas - ao longo do século $X X$, foi aqui tratada num mesmo estudo por terem sido cidades planejadas num contexto específico que é o do Cerrado brasileiro.

É certo que a percepção da natureza do Cerrado e das condições de vida no Planalto Central se alterou consideravelmente ao longo do último século, com o desenvolvimento econômico e social do país. O que equivale a dizer que, para o arquiteto Attilio Corrêa Lima, a construção de uma capital para o estado de Goiás colocou desafios que não subsistiram com a mesma intensidade quando da construção de Palmas. Também as questões relativas à preservação do meio ambiente se impuseram ao longo do século e, se comparecem - de forma admirável - no caso de Goiânia, acabam por tornar-se uma das razões mais anunciadas no memorial de Palmas. Em que pese tudo isso, acreditamos que nosso problema se coloca nos três casos: como essas cidades, em seus planos, se abrem à paisagem do Cerrado; e como esta paisagem, eventualmente, vem nelas representada.

A partir do estudo dos casos pudemos observar que a apropriação do Cerrado enquanto paisagem, por muito que não se efetive em nenhum dos planos das capitais, neles está presente como uma tensão nas relações entre essas capitais e o território. Relações de ambiência, de pertença, de fruição ou negação.

Ao resumir os resultados encontrados, podemos dividi-los em duas correntes principais, a saber: a proposição do Cerrado enquanto paisagem, através intencionalidade 
das perspectivas que as cidades abrem do seu entorno; e a representação do Cerrado nos planos, isto é, a apropriação de seus valores que vêm depois incorporados no planejamento dos espaços urbanos das cidades.

Como vimos, o plano de Goiânia não se abre à paisagem, não a oferece à vista. Tal fato indica a dificuldade de apropriação de uma natureza muito distante dos padrões estéticos da cidade. Mas é nessa tomada de posição que vamos colher a nossa questão: a paisagem do Cerrado, em verdade, está no desenho de Goiânia como uma negação. Uma negação que nasce do problema que se impunha ao arquiteto: como construir espaços modernos aqui? E estar ali significava, para Attilio, estar imerso naquela paisagem, nela habitar, mover-se, receber seus influxos. Resultado desta tensão, acreditamos, é a proposta do Parque dos Buritis: uma sobreposição de valores paisagísticos, ainda, talvez, embrionariamente representada.

Em Brasília a questão se inverte. A abertura deliberada ao território mostra que a localização no Planalto Central já não é uma ameaça - é, antes, um desafio estimulante ao gênio moderno. Daí o plano da capital, apto a mobilizar tanto as enormes distâncias para ressaltar sua monumentalidade, quanto o caráter da natureza local para fazer contraponto à sua modernidade. Porém, se o arquiteto soube construir magistralmente um discurso para o olhar, o Cerrado, em Brasília, se apresenta como cenário que pode não ter a profundidade da experiência paisagística original. Indício, talvez, que o Cerrado não se apresentou como genuína paisagem para os planos de Lúcio Costa, talvez seja o fato de que a paisagem não alcance aqui o status de representação: a experiência direta da paisagem não é depurada esteticamente e incorporada no próprio traço da cidade. Se Brasília se abre ao entorno, seus espaços livres ainda não fazem referência à paisagem que se apresenta.

Palmas, a mais nova das capitais, parece colocar questões bastante diversas. $\bigcirc$ Cerrado vem nominado em seu memorial, à diferença dos outros dois casos, e a sua preservação e a integração da cidade na "natureza" é ventilada como a vantagem maior da futura capital. Mas esta, como vimos, é uma integração direta, que não passa por uma mediação estética - que seria comprovada pela intencionalidade do olhar que a cidade lança ao seu território. Se em Goiânia e em Brasília a resposta fora clara, negativa ou afirmativa, em Palmas a questão parece não ter se colocado com a mesma força. No plano de Palmas não conseguimos encontrar referências à representação do Cerrado em seus espaços urbanos.

\section{Notas}

1 DINIZ, Anamaria. Goiânia de Attilio Corrêa Lima (1932-1935) - Ideal estético e realidade política, 2007. (Ver Bibliografia para referências completas.)

2 LIMA, Attilio Corrêa. Goiânia: A nova capital de Goiás. 1937. In: Revista de Arquitetura e Urbanismo. mai./ jun. de 1937. p. 140.

3 LIMA, Attilio Corrêa. Goiânia: A nova capital de Goiás. 1937. In: Revista de Arquitetura e Urbanismo. jan./ fev. de 1937. p. 34.

4 Todas as citações sem indicação do documento de origem deste capítulo referem-se ao "Relatório do Plano Diretor da Cidade", de Attilio Corrêa Lima (1935). 
5 LIMA, Attilio Corrêa. Goiânia: A nova capital de Goiás. 1937. In: Revista de Arquitetura e Urbanismo. mai./ jun. de 1937. p. 144.

6 Op. Cit. p. 145.

7 Idem.

8 Op. Cit. p. 141-142.

9 Op. Cit. p. 144.

10 A planta dos jardins da Avenida Pedro Ludovico, concebida por Attilio Corrêa Lima, foi publicada em DINIZ, 2007, p. 139. Nela se vêm um parterre a ocupar o canteiro central da avenida, com calçamento e arborização nas extremidades. O tapete de grama é delimitado por cerca de buxinho (Buxus sempervirens L.), pontuada por coníferas. No centro do gramado se desenham leitos retangulares para receber flores - petúnias (Petunia $x$ hybrida) ou flocos (Phlox drummondii Hook.) - ou pequenos espelhos d'água com ninféas (Ninfhaea sp.).

11 A foto do Buritizal e o esboço do Parque dos Buritis (hoje Bosque do Buritis), são parte do acervo de Attilio Corrêa Lima. A foto foi publicada em ACKEL, 2007, p. 203, e o desenho da planta do parque em DINIZ, 2007, p. 140.

12 BRASIL. Edital para o Concurso Nacional do Plano Piloto da Nova Capital do Brasil. Diário Oficial [da] República Federativa do Brasil, Poder Executivo, Brasília, DF, 30 set. 1956. In CODEPLAN. Relatório do Plano Piloto de Brasília. Brasília: GDF, 1991. Disponível em: < http://web.brasiliapoetica.blog.br/site/media/relatorio_plano_piloto_de_brasilia_web2.pdf>. Acessado em: 10 jul. 2011.

13 A escolha do sítio para a construção de Brasília se baseou no Relatório Técnico sobre a Nova Capital da República, o Relatório Belcher (documento que foi também disponibilizado pela comissão organizadora do concurso), que por sua vez, concordou com as indicações feitas nos relatórios das missões lideradas pelo belga Luíz Cruls (Comissão Exploradora do Planalto Central do Brasil, 1892-1893 e Comissão de Estudos da Nova Capital da União, 1894-1895).

14 Todas as citações sem indicação do documento de origem deste capítulo referem-se ao texto de Lúcio Costa, "Memória Descritiva do Plano Piloto", de 1957.

15 COSTA, Lúcio. Eixo Rodoviário-Residencial. In: COSTA, Lúcio. Lúcio Costa: Registro de uma vivência. São Paulo: Empresa das Artes, 1995. p. 308.

16 COSTA, Lúcio. Brasília Revisitada, 1985-1987: Complementação, adensamento, preservação e expansão urbana. p 72 .

17 Os dois grandes eixos de Brasília foram concebidos com suas áreas verdes apenas gramadas. Na Memória do Plano Lúcio Costa descreveu o centro do eixo monumental como uma "esplanada - o Mall, dos ingleses -, extenso gramado destinado a pedestres [...]." , e sobre o eixo rodoviário-monumental, que teria "sempre campo livre nas faixas verdes contíguas às pistas de rolamento". No texto Brasília 57-85: Do plano-piloto ao Plano Piloto, redigido sob sua coordenação, afirma que "A proposta paisagística para o canteiro central da Esplanada se restringe ao gramado contínuo e às massas laterais de paineiras já plantadas" (LIMA e COSTA, 1985, p. 49), e depois sobre o eixo rodoviário-monumental: "No que diz respeito ao paisagismo, a diretriz original, do próprio Lúcio Costa, previa o canteiro central apenas gramado, sendo arborizada a área em torno das "tesourinhas" de forma livre, e as cercaduras das Superquadras de forma disciplinada. A sequência das faixas verdes das quadras, que deveria ser interrompida pelas entrequadras, tornaria legível o próprio plano através da ordenação das massas verdes. (LIMA e COSTA, 1985, p. 101).

18 Entrevista de Lúcio Costa à Revista Manchete, em 1974, republicada em COSTA, Lúcio. Considerações fundamentais. In: COSTA, Lúcio. Lúcio Costa: Registro de uma vivência. São Paulo: Empresa das Artes, 1995. p. 323.

19 COSTA, Lúcio. Brasília Revisitada, 1985-1987: Complementação, adensamento, preservação e expansão urbana. p 71.

20 COSTA, Lúcio. Memória do Plano Piloto de Brasília, 1957.

21 COSTA, Lúcio. O urbanista defende sua cidade, 1967. p. 14.

22 COSTA, Lúcio. Considerações em torno do Plano Piloto de Brasília. (1974). In: Anais. I Seminário de Estudos dos Problemas Urbanos de Brasília. Estudos e Debates. Brasília: Senado Federal, 1974. p.23. apud SCHELLE, Andrey Rosenthal e DONATO, Lila. A praça do maquis. Anais. $7^{\circ}$ Seminário Docomomo Brasil. Porto Alegre, 2007.

23 No dia 7 de dezembro de 1988, o governador ligou para o arquiteto Luiz Fernando: "Eu queria que você viesse aqui no meu gabinete com o centro geográfico do Estado do Tocantins." "Aí ele desenhou o quadrilátero de 90 por 90 km em cima do mapa que eu levei pra ele, e falou assim: 'Eu vou ali, eu acho que nós vamos fazer uma capital." (Teixeira, 2011). Nesse mesmo dia Siqueira "entrou em contato de imediato com o Deputado eleito, Raimundo Boi, a quem revelou a intenção de escolher Miracema como capital provisória, desde que o mesmo deputado e o prefeito eleito da cidade, Sebastião Borba, concordassem com a condição de provisória até 15 de setembro de 1989" (Almeida e Meneses, 1999). À noite, o próprio Siqueira fez um pronunciamento na televisão sobre a escolha de Miracema do Norte como capital provisória, sem se referir nessa ocasião à construção de uma capital.

24 ALMEIDA, Américo Ricardo Moreira de; MENEZES, Pedro Luiz. Ecologia e População: Palmas, a Última Capital Planejada do Milênio. (Ver Bibliografia para a referência completa.) 
25 TEIXEIRA, Luiz Fernando Cruvinel. Entrevista concedida ao autor em Goiânia, no dia 24 de maio de 2011.

26 Idem.

27 TEIXEIRA, Luiz Fernando Cruvinel. Entrevista concedida ao autor em Goiânia, no dia 24 de maio de 2011 : “O resto, aí vem um pouco do Siqueira Campos, pois lá tinha um morrinho, ele me chamou e falou assim: 'Tá vendo esse morrinho aí? Eu quero meu palácio em cima.' O Walfredo disse assim: 'Governador, quem vai dizer pro senhor onde vai ficar o palácio sou eu.' Então o Siqueira respondeu: 'Então você está demitido hoje'. E ainda falou assim: "E eu quero uma avenida de 300 metros pra levar no palácio!' A gente informou a ele que bastaria ser de 150 metros, como Brasília. E ele disse: 'Eu quero!' Então, com esse feito, você tinha os fundos de vale, o lago e a serra, e aí ele chegou e colocou o palácio dele e uma avenida."

28 Na entrevista concedida à SILVA (2008): "Nós tínhamos essa grande avenida aqui, que era a Avenida do Siqueira, que nós não podíamos deixar de atendê-lo. Então nós fizemos a avenida, não com os $300 \mathrm{~m}$ dele, mas tinha que, de certa forma, ainda marca muito, e marcamos o centro dela onde ia ser o Palácio." Em SILVA, Valéria Cristina Pereira da. "Girassóis de pedra": Imagens e Metáforas de uma cidade em busca do tempo, 2008. p. 80.

29 Todas as citações não referenciadas sobre Palmas se referem ao Projeto da Capital do Estado do Tocantins: Plano Básico/Memória, de 1989, documento elaborado pelo GurpoQuatro S/C e que faz parte do Projeto da Capital do Estado do Tocantins, de 1989.

30 TEIXEIRA, Luiz Fernando Cruvinel. Entrevista concedida ao autor em Goiânia, no dia 24 de maio de 2011.

31 Em SILVA, Valéria Cristina Pereira da. "Girassóis de pedra": Imagens e Metáforas de uma cidade em busca do tempo. 2008. p. 79.

32 TEIXEIRA, Luiz Fernando Cruvinel e FILHO, Walfredo Antunes de Oliveira. O ideal e o real. Entrevista a Hugo Segawa, 1991. p. 105.

33 TEIXEIRA, Luiz Fernando Cruvinel e FILHO, Walfredo Antunes de Oliveira. O ideal e o real. Entrevista a Hugo Segawa. 1991. p. 105.

34 TEIXEIRA, Luiz Fernando Cruvinel. Entrevista concedida ao autor em Goiânia, no dia 24 de maio de 2011.

35 TEIXEIRA, Luiz Fernando Cruvinel e FILHO, Walfredo Antunes de Oliveira. O ideal e o real. Entrevista a Hugo Segawa. p. 103.

36 "A gente pega o helicóptero e aí você vê bem essas coisas [a conformação topográfica], porque não tinha Google". TEIXEIRA, Luiz Fernando Cruvinel. Entrevista concedida ao autor em Goiânia, no dia 24 de maio de 2011.

37 "O Siqueira nos obrigou a desenhar isso aqui [a antiga ligação entre os trechos norte e sul da Avenida Principal, que cortava a praça dos girassóis circundando o Palácio do Governo]. Quando ele entrou no segundo governo ele viu o erro que tinha cometido, e pediu que fizesse esse desenho e a praça ficou sem essa passagem no meio, ficou uma praça inteira." TEIXEIRA, Luiz Fernando Cruvinel. Entrevista concedida ao autor em Goiânia, no dia 24 de maio de 2011.

\section{Bibliografia}

ACKEL, Luiz Gonzaga Montans. Attílio Corrêa Lima: Uma trajetória para a modernidade. 2007. 342 p. Tese (Doutorado) - Faculdade da Arquitetura e Urbanismo da Universidade de São Paulo. São Paulo. 2007.

ALMEIDA, Américo Ricardo Moreira de, e MENEZES, Pedro Luiz. Ecologia e População: Palmas, a última capital planejada do milênio. Palmas, 1999. Disponível em: http://www.ricardoalmeida.adm.br/palmas.php>. Acesso em: 01 jun. 2011.

BARKI, José. O Risco e a Invenção: Um Estudo sobre as notações gráficas de concepção no projeto. 2003. 270 p. Tese (Doutorado) -. Faculdade de Arquitetura e Urbanismo da Universidade Federal do Rio de Janeiro. Rio de Janeiro. 2003. Disponível em: <http://teses.ufri.br/FAU_D/JoseBarki.pdf>. Acesso em: 15 jul. 2011.

BRASIL. Edital para o Concurso Nacional do Plano Piloto da Nova Capital do Brasil. In: Diário Oficial da República Federativa do Brasil. Poder Executivo, Brasília, DF, 30 set. 1956. Disponível em: http://www.infobrasilia.com.br/ documentos.htm. Acesso em 10 dez. 2005. Acessado em 14 jun. 2011.

CARVAlHO, Luiz de. História de Palmas em capítulos. Sem data. Disponível em: <http://portalaqui.com/index. php/palmas-a-capital.html>. Acesso em 02 de maio de 2011.

COSTA, Lúcio. Brasília revisitada (1987). In COSTA, Lúcio. Lúcio Costa: Registro de uma vivência. São Paulo: Empresa das Artes, 1995. p. 330-331.

. Brasília Revisitada, 1985-1987: complementação, adensamento, preservação e expansão urbana. Anexo I do Decreto 10.829. Diário Oficial do Distrito Federal, 14 de outubro de 1987. In: LEITÃO, Francisco (Org.). Brasília 1960 - 2010: Passado, presente e futuro. Brasília: Secretaria de Estado de Desenvolvimento Urbano e Meio Am- 
biente, 2009. p. 69-78. Disponível em: <http://docomomobsb.files.wordpress.com/2010/04/brasilia-1960-2010. pdf> Acesso em: 10 jun. 2011.

Memória descritiva do plano piloto. (1957). In: COSTA, Lúcio. Lúcio Costa: Registro de uma vivência. São Paulo: Empresa das Artes, 1995. P. 283-297. Disponível em: <http://docomomobsb.files.wordpress.com/2010/04/ brasilia-1960-2010.pdf> Acesso em: 10 jun. 2011.

O urbanista defende sua cidade (1967). In: LIMA, Adenildo Viegas de; COSTA, Maria Elisa. Brasília 57-85: Do plano-piloto ao Plano Piloto. Brasília: Terracap, 1985. Disponível em: <http://www.sedhab.df.gov. br/005/00502001.asp?HCD_CHAVE=15812>. Acesso em: 04 jun. 2011.

DINIZ, Anamaria. Goiânia de Attilio Corrêa Lima (1932-1935) - Ideal estético e realidade política. Dissertação (Mestrado) - Faculdade de Arquitetura e Urbanismo da Universidade de Brasília. Brasília. 2007.

GRUPOQUATRO S/C. Projeto da capital do Estado do Tocantins: Plano Básico/Memória. Palmas, 1989 (Mimeo.).

GUSMÃO, Cristiane. Escala bucólica: Os três mosqueteiros são quatro. In: LEITÃO, Francisco (Org.). Brasília 1960 - 2010: Passado, presente e futuro. Brasília: Secretaria de Estado de Desenvolvimento Urbano e Meio Ambiente, 2009. p. 159-182. Disponível em: <http://docomomobsb.files.wordpress.com/2010/04/brasilia-1960-2010.pdf>. Acessado em: 12 de jun. de 2011.

JUNIOR, Oscar Sabino (Org.). Goiânia documentada. São Paulo: Edigraf, 1960.

LEITÃO, Francisco (Org.). Brasília 1960 - 2010: Passado, presente e futuro. Brasília: Secretaria de Estado de Desenvolvimento Urbano e Meio Ambiente, 2009. p. 159-182. Disponível em: <http://docomomobsb.files.wordpress. com/2010/04/brasilia-1960-2010.pdf>. Acessado em: 12 de jun. de 2011.

LIMA, Adenildo Viegas de; COSTA, Maria Elisa. Brasília 57-85: Do plano-piloto ao Plano Piloto. Brasília: Terracap, 1985. Disponível em: <http://www.sedhab.df.gov.br/005/00502001.asp?ttCD_CHAVE=15812>. Acesso em: 04 jun. 2011.

LIMA, Attilio Corrêa. Relatório do Plano Diretor da Cidade. 1935. In: JUNIOR, Oscar Sabino (Org.). Goiânia documentada. São Paulo: Edigraf, 1960. p. 95-111.

Goiânia: A nova capital de Goiás. 1937. In: Revista de Arquitetura e Urbanismo. jan./fev., mar./abr. e mai./jun. de 1937.

Revista PROJETO, n. 146. São Paulo: Projeto Editores Associados Ltda., 1991.

SCHELLE, Andrey Rosenthal; DONATO, Lila. A praça do maquis. $7^{\circ}$ Seminário Docomomo Brasil. In: Anais... Porto Alegre, 2007. Disponível em: <http://www.docomomo.org.br/seminario\%207\%20pdfs/001.pdf>. Acesso em 02 de mai. 2011.

SILVA, Valéria Cristina Pereira da. "Girassóis de pedra": Imagens e metáforas de uma cidade em busca do tempo. 2008. Tese (Doutorado) - Universidade Estadual Paulista. Presidente Prudente. 2008. Disponível em: <http://www4. fct.unesp.br/pos/geo/dis teses/08/valeriacristina.pdf>. Acesso em 20 jun. 2011.

SIMMEL, G.. Filosofia da paisagem. In: SIMMEL, G. La tragédie de la culture et autres essais. (1913). Trad. Cornille S. e lvernel P.. Paris: Editions Riveges, 1988. (Trad. Bartalini, V. para uso exclusivo na disciplina AUP 5882, FAUUSP, 2008.)

TEIXEIRA, Luiz Fernando Cruvinel. Entrevista concedida em Goiânia no dia 24 de maio de 2011.

; FILHO, Walfredo Antunes de Oliveira. O ideal e o real. Entrevista a Hugo Segawa. In: Revista Projeto, n. 146. São Paulo: Projeto Editores Associados Ltda., 1991.

. A formação de Palmas. Dossiê Cidades Planejadas na Hinterlândia. In: Revista UFG, ano XI, jun. 2009, n. 6, p. 91-99. Disponível em: <http://www.proec.ufg.br/revista_ufg/junho2009/Palmas.pdf>. Acesso em 28 mai. 2011. 
